\title{
PREDICTORS OF EFFECTIVE USE OF T CELL MIMETICS IN IMMUNE AND ENDOCRINE DISORDERS TREATMENT
}

\author{
D.S. Luybimov, A.N. Britanov
}

Rostov State Medical University, Rostov-on-don, Russia

\section{ПРЕДИКТОРЫ ЭФФЕКТИВНОСТИ Т-КЛЕТОЧНЫХ МИМЕТИКОВ В КОРРЕКЦИИ ИММУННОЙ И ЭНДОКРИННОЙ ДИСФУНКЦИИ}

\author{
Д.С. Любимов, А.Н. Британов \\ ФГБОУ ВО «Ростовский государственный медицинский университет» Минздрава России, \\ Ростов-на Дону
}

\begin{abstract}
98 infants with acute bronchitis aged 3-36 months showed general basic adaptive response on the acute stage: depression of cellular immune response, active humoral immune response, CIC increase and enhanced phagocytic capacity of neutrophils. ACTH and TSH levels were elevated against depletion of cortisol and triiodothyronine levels. Clinical markers together with immune and endocrine predictive markers of the disease severity, character of complications and comorbidity were revealed. Thymogen is indicated for treatment in case of prevailing of hyperergic disorders both in the central core of neurohumoral regulation and the intraimmune - IgA increase. Thymaline proves effective in hyperergia treatment - thymomegaly with low IgA and cortisol levels along with pre-existing bacterial infections.
\end{abstract}

Keywords: predictor; timomegaly; thymalin; timogen; bronchitis.

У 98 детей с острым бронхитом в возрасте от 3 до 36 месяцев в остром периоде бронхита наблюдалась общая базисная адаптационная реакция: супрессия клеточного, активация гуморального звеньев иммунитета, увеличение количества ЦИК и повышение поглотительной способности нейтрофилов. Уровни АКТГ и ТТГ были повышены на фоне снижения кортизола и ТЗ. Были выявлены клинические маркеры, иммунные и эндокринные предикторы тяжести течения заболевания, характера осложнений и особенностей сопутствующих заболеваний. Тимоген показан при преобладании гиперэргических нарушениях как в центральном звене нейрогуморальной регуляции так и интраиммунном - увеличение IgA. Тималин эффективен при гипоэргии - тимомегалия с низким уровнем IgA и кортизола, а также с бактериальными инфекциями в анамнезе.

Ключевые слова: предиктор; тимомегалия; тималин; тимоген; бронхит.

Introduction. Presently the work on finding predictive markers that would guarantee high efficiency of immune therapy is in progress. Significant amount of newborns with complicated bronchitis have strong clinical evidences of unfavorable course of perinatal period with developmental disorders in central organs of nervous and immune regulation resulting in perinatal encephalopathy and thymomegalia. Taking into account thymus immaturity with the leading role of $\mathrm{T}$ component of the immune system in pathogenesis of viral infections, it seems reasonable to include $\mathrm{T}$ mimetics into infants' bronchitis therapy. The aim of this study was to find clinical and laboratory predictive markers of the efficiency of thymic peptidic thymalin extract and synthetic thymogen dipeptide use in basic treatment of respiratory viral infection in infants.

Material and methods. 98 infants with acute bronchitis aged 3-36 months were observed. 42 of them received basic therapy complemented by thymalin $(0.2 \mathrm{mcg} / \mathrm{kg}), 20$ received thymogen $(2 \mathrm{mcg} / \mathrm{kg})$. The control group included 36 infants close in age, gender and the course of a disease with two main groups. At the acute and recovery stages CD lymphocytes, immunoglobulins, CIC, phagocytic capacity of neutrophils (latex-stimulated) and hormones Hypothalamic-Pituitary-Adrenal (ACTH, cortisol) and Hypothalamic-PituitaryThyroid (TSH, thyroxine, triiodothyronine) axes were controlled.

All the 98 infants on acute bronchitis stage showed general basic adaptive response: depression of cellular immune response, active humoral immune response, CIC increase and enhanced phagocytic capacity of neutrophils. The central core of endocrine regulation showed two to threefold rise in ACTH and TSH against depletion of cortisol and triiodothyronine level. Thyroxin level was the same among both intact and infected infants. In the setting of general adaptive response laboratory and clinical predictive markers were revealed that made it possible to differentiate between two types of regulation disorders.

Results and discussion. The first type was characterized by mostly hyperergic character at all regulation levels, which was clinically revealed by catastrophic course of the disease with significant 
intoxication accompanied by fever, intense exudation in lower lobe bronchus (75\% had mostly medium moist rales). One in five infants had acetonemic vomiting, $25 \%$ had symptomatic epilepsy, while more than a half of boys over one year old with obstructive bronchitis suffered from convulsive attacks. Therewith cases of thymomegaly and perinatal encephalopathy among these infants were few. Changes in cellular component of immune system were minimal and apocryphal, humoral component showed significant hypergammaglobulinemia, especially due to $\operatorname{Ig}$ A $(0.91 \pm 0,05 \mathrm{~g} / \mathrm{l})$. Hypophysiotropic hormones level was at highest among all infants observed along with moderate cortisol and triiodothyronine decrease.

20 infants with this hyperergic type of central and intra-immune regulation disorder against relative viability of cellular proliferation and differentiation received synthetic thymogen dipeptide (Alfa-glutamyl-tryptophan), which led to normalization of immune and endocrine parameters and prevented complications and backsets of infections.

The second, intra-immune type of regulation disorder developed mostly among boys (32 out of 42) and was clinically revealed in a significant amount of bacterial infections (otitis, furunculosis pneumonia), while on the immune level it showed itself in a very low $\operatorname{IgA}$ level $(0,27 \pm 0,04 \mathrm{~g} / \mathrm{l})$, which is evidently a result of insufficient provision of B cells by Th-2 interleukines. B cells activation manifested in B-lymphemia, significant rise in Ig $M$ and CIS. Ig $G$ level showed high differentiation - a part of infants had a significant decrease, while the others had a rise. Immunoregulatory index decreased $(0.87 \pm 0.03$ in all age groups due to firm reduction of $\mathrm{CD} 4^{+}$cells $(24.6 \pm 0.62 \%)$.

Depending on thyroid body, adrenal and thymus state this type of regulation disorder has two ways of respiratory viral infection course. The first one supposes strong obstruction among infants aged 6-24 months with thymomegaly, hypocorticism $(234.7 \pm 26.8 \mathrm{nM} / 1)$, T-lymphemia, rise in $\mathrm{CD}^{+}$cells $(27,5 \pm 0.38 \%)$ and a very low $\mathrm{A}$ and $\mathrm{G}$ immunoglobulins level.

Respiratory infection among these infants is characterized by significant obstruction, intoxication and respiratory depression. The second type of patients is adrenal and thymus function preserved, so the respiratory infection is characterized by no obstruction but greater amount of bacterial and viral infections. The family medical history shows high frequency of ENT pathology. Complex treatment for 42 infants of the second group includes thymalin containing multiple peptides aimed at enhancing the function of T-helper cells and normalizing immune and endocrine functions. The medication proved to significantly raise the effectiveness of the basic therapy, prevent new respiratory infections and normalize laboratory values: IgA doubled from 0.27 to $0.58 \mathrm{~g} / \mathrm{l}$.

Conclusion. Summing up, catastrophic and hyperergic character of the infection course can be regarded as clinical markers that justify inclusion of synthetic $\mathrm{T}$-mimetics modulating relatively mature immune-competent cells, while high A immunoglobulin level and subnormal amount and correlation of $T$ cells can be regarded as laboratory predictive markers. For mostly boys with thymomegaly and pre-existing bacterial infections (otitis, furunculosis pneumonia) along with low IgA and cortisol level thymaline thymic extract is indicated for treatment that can enhance cell functions as well as effectors and regulators of immune response. For more precise choice of T-mimetics it would be reasonable to match the medical history and the course of the disease with investigation of helper cell mediators of the first and the second type. 